\title{
LJUBLJANSKA URBANA REGIJA - PROBLEMSKA REGIJA?
}

\author{
Simon Kušar", Katja Vintar Mally"* \\ Oddelek za geografijo, Filozofska fakulteta, Univerza v Ljubljani, \\ Aškerčeva 2, 1000 Ljubljana, Slovenija \\ *e-mail: simon.kusar@ff.uni-lj.si \\ * e-mail: katja.vintar@ff.uni-lj.si
}

\begin{abstract}
Izvleček
Zgostitvene regije so poseben tip problemskih regij s specifičnim spletom razvojnih problemov. S pomočjo analize procesov in stanja na gospodarskem, demografskem, socialnem, prostorskem in okoljskem področju v Ljubljanski urbani regiji so izpostavljeni poglavitni problemi v regiji in temeljni vzroki zanje. Izsledki v celoti potrjujejo začetno domnevo, da ima obravnavana regija vse značilnosti zgostitvenega tipa problemskih regij.
\end{abstract}

Ključne besede: regionalni razvoj, problemska regija, Ljubljanska urbana regija, Ljubljana, Slovenija

\section{LJUBLJANA URBAN REGION - A PROBLEM REGION?}

\begin{abstract}
Agglomerative regions are a special type of problem regions with a specific set of development problems. An analysis of the economic, demographic, social, spatial and environmental processes and the situation in the Ljubljana urban region has highlighted the main problems in the region and the reasons behind them. The results fully confirmed the initial assumption that the region in question has all the characteristics of the agglomerative type of problem regions.
\end{abstract}

Key words: regional development, problem region, Ljubljana urban region, Ljubljana, Slovenia 


\section{UVOD}

Ljubljanska urbana regija (LUR) je glede na standardno klasifikacijo teritorialnih enot $\mathrm{v}$ Sloveniji ena izmed dveh enot na SKTE 2 ravni in prostorsko sovpada z Osrednjeslovensko statistično regijo, ki je opredeljena v sklopu razdelitve Slovenije na 12 statističnih regij (SKTE 3 raven). Ljubljansko urbano regijo sestavlja 24 občin, med njimi tudi po površini in številu prebivalstva največja Mestna občina Ljubljana.

O razvojnih značilnostih Ljubljanske urbane regije se ponavadi govori samo s presežniki: je najgosteje poseljena regija $\mathrm{v}$ Sloveniji, gospodarsko najbolj razvita in regija $\mathrm{z}$ najbolje ocenjenimi razvojnimi možnostmi (SRRS, 2001). Toda ali ima Ljubljanska urbana regija zaradi tako močne zgostitve prebivalcev, delovnih mest in dejavnosti značilnosti problemske regije? Na to vprašanje bo $\mathrm{z}$ analizo procesov in stanja na gospodarskem, demografskem, socialnem, prostorskem in okoljskem področju skušal odgovoriti ta prispevek.

Slika 1: Ljubljanska urbana regija - upravna delitev na občine

Figure 1: Units of local selfgovernance in Ljubljana urban region

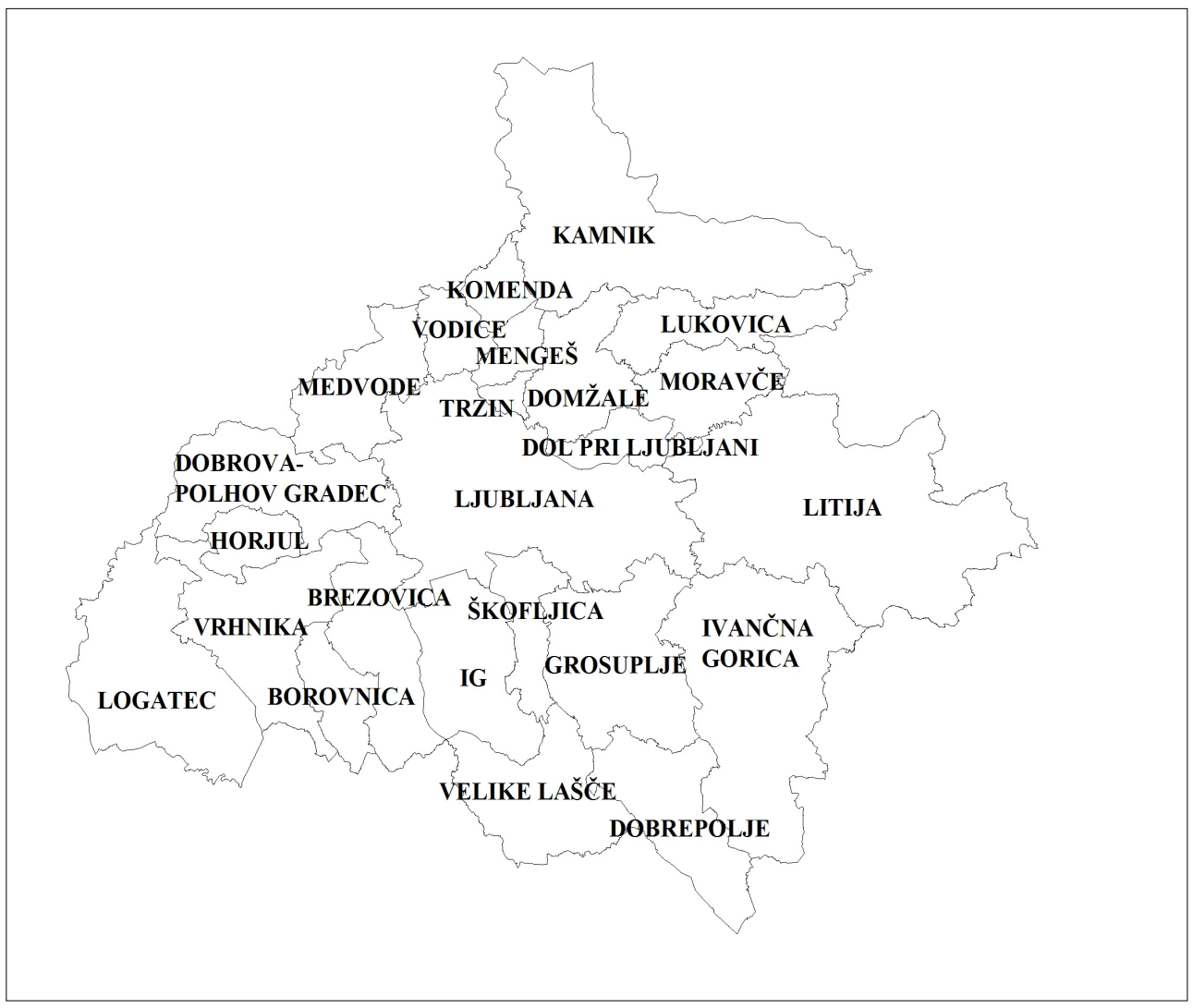




\section{ZGOSTITVENA REGIJA KOT POSEBEN TIP PROBLEMSKE REGIJE}

Vsaka regija postane problemska takrat, ko se v njej pojavljajo takšni in tako veliki razvojni problemi, da je zaznava prostora kot harmonične geografske celote presežena, nadaljnji gospodarski razvoj ogrožen, kakovost življenja pa tudi zaradi povečanih okoljskih pritiskov zmanjšana (Kušar, 2003a).

Ponavadi se kot problemske regije označujejo le manj razvite regije, ki se srečujejo $\mathrm{z}$ gospodarskim zastojem, visoko stopnjo brezposelnosti, depopulacijo in staranjem prebivalstva. Številne raziskave in praktični primeri kažejo, da je med posebne tipe problemskih regij zaradi posebnih razvojnih problemov potrebno uvrščati tudi najbolj razvite regije. Največkrat citiran takšen primer je regija Jugovzhod v Veliki Britaniji, kjer je v 80. letih 20. stoletja prišlo do izjemnega gospodarskega napredka, ki pa je s seboj prinesel veliko razvojnih problemov predvsem s socialnega, prostorskega in okoljskega področja (glej npr. Allen et al., 1998).

Za zgostitvene regije so značilne naslednje razvojne težnje: hiter gospodarski in populacijski razvoj, zgoščevanje prebivalcev in delovnih mest, kapitala, raziskovalnih institucij, uprave in kulturnih ustanov (Regional Inequalities, 2001). Zgostitve so rezultat številnih geografskih dejavnikov, vendar se razlogi zanje kljub temu iščejo pretežno v ekonomiji (npr. Kebrič, Mrzlikar, 1983), saj ekonomija velikosti omogoča najugodnejše razmerje med stroški in dobičkom. Kopičenje dejavnosti in prebivalcev lahko preseže okvir posameznih naselij ali manjših območij in zajame celotno regijo ali celo več regij hkrati (Armstrong, Taylor, 2000). Intenzivna koncentracija postopoma vodi do številnih gospodarskih, socialnih, urbanih, prostorskih in okoljskih problemov. Ti se lahko reproducirajo do takšne mere, da so ogroženi nadaljnji gospodarski razvoj, kakovost bivanja prebivalcev in okolja. Zgostitveno območje zato postane problemska regija (Discuss..., 1991; Kušar, 2003a).

Regionalni problemi v zgostitveni regiji so med seboj močno povezani. Zaradi obsežne dnevne migracije delovne sile iz suburbanih območij v mesta je potrebno stalno povečevati kapacitete cest in železnic, ki pa nikoli ne zadostijo vedno večjim potrebam. Naraščanje prometa vpliva na povečevanje obremenjevanja okolja tako z naraščanjem emisij dušikovih oksidov, pojavom troposferskega ozona in hrupom kot tudi s povečevanjem obsega površin namenjenih komunikacijam. Vedno nove investicije v prometno omrežje močno bremenijo mestni, regionalni in državni proračun. Potrebni so visoki izdatki za zagotavljanje ustrezne infrastrukture in javnih storitev. Zaradi zastojev na cestah se povečujejo poraba neobnovljivih virov, denarja in časa. Veliko povpraševanje po stanovanjih, poslovnih prostorih in zazidljivih površinah vpliva na poviševanje cen nepremičnin. Zaradi obsežne gradnje se urbane površine širijo, predvsem na račun zadnjih ostankov odprtega prostora (kmetijskih površin in gozdov). Povečani življenjski stroški silijo delovno silo k dvigu osebnih dohodkov ali pa se je primorana izseliti v regije z nižjimi življenjskimi stroški. Povečujeta se socialna segregacija in stopnja kriminalitete. Pojavljajo se tudi problemi povezani s staranjem in neustrezno usposobljenostjo delovne sile za sprejemanje novosti, inovacij in postindustrijskega načina gospodarjenja, kar se odraža v višji stopnji brezposelnosti med nižje izobraženimi socialnimi skupinami (Allen et al., 1998; Armstrong, Taylor, 2000; Discuss..., 1991; Kušar, 2003a; Regional Inequalities, 2001). 
Zgostitvena regija ni nujno razvojno homogena. Razvoj (in z njim povezani problemi) je ponavadi posebno intenziven $v$ t.i. vročih točkah, to je v posameznih delih regije. Nekateri drugi deli regije se lahko kljub relativni bližini vročih točk srečujejo s povsem drugačnimi razvojnimi problemi, ki bolj spominjajo na tiste $v$ manj razvitih regijah. Kljub temu gre v primeru zgostitvenih regij za strukturno koherenco zaradi enakih ekonomskih in socialnih razvojnih procesov ter zaradi medsebojne odvisnosti obrobja in vročih točk (Allen et al., 1998).

\section{REGIONALNA STRUKTURA IN NEKATERI RAZVOJNI PROBLEMI LJUBLJANSKE URBANE REGIJE}

Ljubljanska urbana regija obsega $12,6 \%\left(2.555 \mathrm{~km}^{2}\right)$ površine Slovenije. Ob popisu prebivalcev leta 2002 je štela skoraj 500.000 prebivalcev oziroma $25 \%$ vsega prebivalstva v Sloveniji. V regiji živi v povprečju 191 prebivalcev na kvadratni kilometer, največjo gostoto poselitve pa dosega Mestna občina Ljubljana (967 preb. $/ \mathrm{km}^{2}$ ), v kateri živi približno polovica prebivalcev regije (Statistični..., 2003). Ostala območja zgostitve so ob glavnih cestah, ki so hkrati tudi del V. oziroma X. evropskega koridorja. Proces koncentracije prebivalcev v mestu Ljubljana se zmanjšuje na račun suburbanizacije in dezurbanizacije: število prebivalcev v Ljubljani se zmanjšuje, v obmestnih naseljih, predvsem v tistih, ki imajo ugodno prometno povezavo z regionalnim središčem, pa se povečuje (Gulič, Praper, 2000; Rebernik, 2003).

Ljubljanska urbana regija je imela v zadnjih letih vseskozi najvišji selitveni prirast v Sloveniji in je v medpopisnem obdobju 1991-2002 posledično zabeležila 5,3\% rast prebivalstva, kar dvakratno presega državno povprečje (Statistični..., 2003). V drugi polovici 90. let 20. stoletja je bila polovica priseljencev starih od 20 do 34 let, kar $20 \%$ priseljenih je imelo višjo ali visoko izobrazbo. Ob tem je velik del priselitev povezan s prvo redno zaposlitvijo (Dolenc, 2000). Priselitve niso omejene samo na Ljubljano, ampak so pogosto usmerjene v suburbano območje okrog Ljubljane (Repovž, 2004). Selitev iz Ljubljanske urbane regije je ponavadi povezana z gradnjo oziroma nakupom enodružinske hiše, vendar je izvedena na tako kratki razdalji, da je mogoča dnevna migracija v službo (Dolenc, 2000). Nekateri prebivalci, predvsem tisti s šibkejšim socialnim statusom, zapuščajo LUR zaradi previsokih življenjskih stroškov (Kušar, 2003b).

Selitev iz Ljubljane je pogosto motivirana tudi z visokimi najemninami, pomanjkanjem ustreznih stanovanj ter visokimi cenami stavbnih zemljišč in nepremičnin (Dolenc, 2000). Tržne stanovanjske najemnine v Ljubljani so tudi enkrat višje kot v drugih slovenskih mestih (Cirman, Zupančič, 2003). Cene nepremičnin v LUR znatno presegajo cene nepremičnin v drugih regijah v Sloveniji. V Ljubljanski urbani regiji je leta 2002 povprečna prodajna cena kvadratnega metra stanovanja znašala 1.211 evrov, v večini drugih slovenskih regij pa manj kot polovico omenjenega zneska. Cene nepremičnin so se v večini slovenskih regij v obdobju 2000-2002 zmanjšale, medtem ko so se v LUR, Goriški, Obalnokraški in Podravski statistični regiji povečale. Ob navedenem je potrebno upoštevati, da so cene stanovanj $\mathrm{v}$ Mestni občini Ljubljana bistveno višje kot v drugih delih Ljubljanske urbane regije. 
Preglednica 1: Povprečna prodajna cena kvadratnega metra stanovanj po letih in v regijah (vEUR).

Table 1: Average price of square meter of apartment (in EUR)

\begin{tabular}{|c|c|c|c|c|c|}
\hline \multirow[b]{2}{*}{ statistična regija } & \multirow[b]{2}{*}{2000} & \multirow[b]{2}{*}{2001} & \multirow[b]{2}{*}{2002} & \multicolumn{2}{|c|}{$2000-2002$} \\
\hline & & & & povprečje & $\begin{array}{r}\text { indeks ravni, } \\
\mathrm{SLO}=100\end{array}$ \\
\hline Gorenjska & 754 & 760 & 544 & 686 & 84 \\
\hline Goriška & 632 & 637 & 640 & 636 & 78 \\
\hline Jugovzhodna & 595 & 598 & 580 & 593 & 73 \\
\hline Koroška & 422 & 331 & 255 & 301 & 37 \\
\hline Notranjsko-kraška & 439 & 436 & 422 & 434 & 53 \\
\hline Obalno-kraška & 964 & 1.066 & 1.106 & 1.037 & 127 \\
\hline Osrednjeslovenska (LUR) & 1.135 & 1.191 & 1.211 & 1.172 & 144 \\
\hline Podravska & 534 & 552 & 593 & 559 & 69 \\
\hline Pomurska & 538 & 510 & 467 & 512 & 63 \\
\hline Savinjska & 492 & 490 & 439 & 477 & 59 \\
\hline Spodnjeposavska & 397 & 441 & 368 & 409 & 50 \\
\hline Zasavska & 428 & 434 & 428 & 430 & 53 \\
\hline
\end{tabular}

Vir: Pšunder, Ferlan, 2003, str. 198.

Razlogi za tako visoke cene v LUR so povezani s soodvisnostjo med cenami nepremičnin in gospodarskim blagostanjem v regiji (izraženim s povprečnim dohodkom gospodinjstva ali višino BDP na prebivalca - Bradeško, 2003), velikim povpraševanjem po prostih zazidljivih parcelah, stanovanjih in poslovnih prostorih ter $\mathrm{z}$ neuravnoteženim trgom nepremičnin. V mestu Ljubljana je po podatkih statističnega urada kar 13.480 stanovanj praznih, vendar jih dejansko zasedajo večinoma neprijavljeni prebivalci in študenti (Repovž, 2004), zato se primanjkljaj novih stanovanj v glavnem mestu ocenjuje na 10.000.

Gospodarstvo Ljubljanske urbane regije je izrazito terciarno usmerjeno, saj prispevajo storitvene dejavnosti 70\% dodane vrednosti. Raznovrstna industrija je k celotni ustvarjeni dodani vrednosti prispevala 27\% (Pečar, 2002). Čeprav je LUR gospodarsko najrazvitejša regija in je ustvarjeni BDP na prebivalca leta 2001 za 39\% presegal slovensko povprečje (Statistični..., 2003), se predvsem delovno intenzivna industrija nahaja v izgubah (Pečar, 2002), v primerjavi z drugimi, gospodarsko manj razvitimi slovenskimi regijami, pa je LUR po izvozni usmerjenosti gospodarstva uvrščena na zadnje mesto (Gulič, Praper, 2000).

V regiji je prišlo do odlivanja kapitala v tujino (Repovž, 2004), vendar je ta pojav verjetno posledica globalizacije. Istočasno prihaja tudi do odlivanja finančnih sredstev v druge slovenske regije zaradi dnevnih delovnih migracij, saj zaposleni svoje dohodke odnašajo v občino stalnega prebivališča, v kateri plačujejo tudi dohodnino in druge dajatve. Istemu procesu sledimo tudi znotraj LUR, kar je posebej finančno neugodno za Mestno občino Ljubljana, ki čedalje težje financira ustrezno infrastrukturo in javne storitve, saj velik del njihovih uporabnikov zanje ne plačuje (Repovž, 2004). 
Zaradi krize v tradicionalnih industrijskih panogah se je stopnja brezposelnosti v LUR do sredine 90 . let 20. stoletja povečevala in leta 1998 dosegla 10,5\%. Danes znaša stopnja brezposelnosti manj kot $8 \%$. Med brezposelnimi prevladujejo delavci z nižjimi stopnjami izobrazbe $(44,4 \%)$, ki ne ustrezajo zahtevam sodobnega trga delovne sile. Med brezposelnimi je bilo v prvi polovici leta 2002 le 17,5\% mladih, kar je bil drugi najnižji delež v državi (Pečar, 2002).

V Ljubljanski urbani regiji je 231.000 delovnih mest oziroma $29,6 \%$ vseh delovnih mest v Sloveniji, od tega jih je tri četrtine osredotočenih v Mestni občini Ljubljana, ki je tako najpomembnejše zaposlitveno središče v Sloveniji (Černe, 2002). Decentralizaciji bivanja ni sledila enako intenzivna decentralizacija delovnih mest (Repovž, 2004). Rezultat tega neravnovesja so obsežne dnevne migracije in s tem intenzivni prometni tokovi. Na delovno mesto $\mathrm{v}$ Ljubljano dnevno $\mathrm{z}$ osebnim avtomobilom pripotuje 35.000 prebivalcev LUR, upoštevati pa je potrebno, da gravitacijski vpliv Ljubljane sega tudi izven Ljubljanske urbane regije. Ker je povprečna zasedenost avtomobila le 1,28 osebe, Gabrovec in ostali (2000) ocenjujejo, da pripelje v Ljubljano iz območja LUR vsak dan približno 25.000 vozil. Javni promet se uporablja le za $10-20 \%$ vseh potovanj. Ker so v ta delež vključeni tudi dijaki in upokojenci, delež zaposlenih, ki uporablja javni prevoz, ne dosega $10 \%$. Rezultat visoke osebne motorizacije so zastoji na mestnih vpadnicah in pomanjkanje parkirnih mest (Gabrovec et al., 2000).

Pomen javnega potniškega prevoza se v Sloveniji in v LUR zmanjšuje vse od sredine 80. let 20. stoletja na račun povečevanja uporabe osebnega avtomobila (Černe, 2002). Razlogi za takšen upad pomena javnega prometa so povezani z visoko stopnjo motorizacije, razpršeno poselitvijo, ki se s suburbanizacijo in dezurbanizacijo še povečuje, in z zaostankom pri posodabljanju javnega potniškega prometa (Černe, 2002). Ceste na območju LUR so med najbolj obremenjenimi v Sloveniji. Velik pritisk dnevnih migrantov je usmerjen tudi na železnico, tako da ta $\mathrm{v}$ konicah s svojimi prevoznimi sredstvi ne more zagotoviti ustreznih kapacitet. Pred kratkim odprta vzhodna avtocestna obvoznica, ki je bila skupen projekt države in mestne občine, je že tako obremenjena, kot naj bi po bila po načrtih šele čez nekaj let. Z globalizacijo se pričakuje še povečana mobilnost prebivalstva (Ravbar, 2002), kar bo prometne razmere v Ljubljanski urbani regiji še poslabšalo. Tuji obiskovalci že sedaj opozarjajo, da so prometni problemi in slabo delujoči javni potniški promet resna ovira za kakovostno bivanje in uspešno poslovanje $\mathrm{v}$ prihodnosti (Trajnostni..., 2002).

Zaradi suburbanizacije prihaja do nepovratnega izgubljanja ekološko pomembnega odprtega prostora. Prostorska struktura poselitve v LUR je zelo potratna, saj so se v širši okolici Ljubljane ob podvojitvi števila prebivalstva po drugi svetovni vojni poseljene površine povečale kar za sedemkrat. V primerjavi z drugimi mesti v Evropi se je v Ljubljani za vsakega novega prebivalca porabilo štiri do petkrat več površin (Trajnostni..., 2002). Tudi danes se trend razpršene gradnje individualnih bivališč nadaljuje (Ravbar, 2002), kar je nenazadnje razvidno tudi iz stalnega povečevanja obsega pozidanih površin, ki je leta 2001 dosegel 11.167 ha ali 4,4\% površja regije (slovensko povprečje: 2,8\%), k čemer je potrebno prišteti še dodatne $1,3 \% \mathrm{~s}$ cestami in železnicami zasedenega površja. Primerjave podatkov kažejo, da so se samo v obdobju 1993-1999 pozidane površine v Sloveniji povečale za 1.459 ha na račun kmetijskih zemljišč, tako na obrobjih mest kot tudi na območjih kmetij- 
skih površin prve kakovosti. Omenjeni proces je bil najbolj izrazit v LUR ter v Podravski in Savinjski regiji, predvsem v zadnjih dveh proučevanih letih (Šabić et al., 2000). V LUR je še dodatno problematično širjenje pozidanih površin na območja pomembna za vodno oskrbo, kar kaže na potrebo po pretehtanem usmerjanju poselitve in preprečevanju nadaljevanja stihijske pozidave na podeželju. V primerjavi z obsegom obstoječih pritiskov na sestavine okolja pa izstopa tudi pomanjkanje ustreznih ekološko izravnalnih območij kot so na primer zavarovana območja. Slednja predstavljajo le $0,4 \%$ površja regije, kar je najnižji delež med 12 slovenskimi statističnimi regijami (Vintar, 2003).

Zgoščevanje prebivalstva in dejavnosti v Ljubljanski urbani regiji se na okoljskem področju negativno odraža predvsem v kakovosti voda in zraka, pri čemer izrazito izstopa osrčje regije. Čeprav so se povprečne koncentracije žveplovega dioksida in kislih plinov v drugi polovici 90 . let 20. stoletja večinoma znižale, so rezultati meritev v regiji še vedno nad slovenskim povprečjem. Zniževanje emisij je bilo v veliki meri doseženo z zamenjavo goriv in uveljavitvijo daljinskega ogrevanja, po razširjenosti katerega je Ljubljana vodilna $v$ državi, vendar so rezerve še precejšnje, saj je prevladujoče gorivo za daljinske sisteme še vedno premog. Po drugi strani pa so čedalje bolj problematične koncentracije dušikovih oksidov in ozona, pri katerem prihaja v Ljubljani nekaj deset dni letno do preseganja mejnih dnevnih vrednosti (Onesnaženost..., 2002). Podobno situacijo gre verjetno pričakovati tudi v drugih mestnih središčih in vzdolž večjih prometnic (Regionalni..., 2002), saj sta glavni vir omenjenih emisij predvsem promet in energetika. Posledično tako namesto klasične zimske v ospredje že stopa poletna onesnaženost zraka.

Problematična je tudi kakovost voda v regiji, saj meritve kažejo na močno onesnaženost vodotokov v širši okolici Ljubljane, kjer se v 3.-4. ali celo 4. kakovostni razred uvrščajo Ljubljanica pri Zalogu, Kamniška Bistrica pred izlivom in Sava pri Dolskem (Monitoring kakovosti površinskih..., 2001). Regijsko povprečje izboljšujejo rezultati meritev v povirnih območjih Ljubljanice, Kamniške Bistrice in Krke. Na kakovost voda v veliki meri vplivajo neprečiščene odpadne vode iz gospodinjstev in gospodarstva, saj so kapacitete obstoječih čistilnih naprav preskromne, stopnja čiščenja pa prenizka. Ljubljanska čistilna naprava (360.000 PE) zagotavlja le mehansko čiščenje in naj bi bila dokončno izgrajena leta 2005, tako da je edina večja in učinkovitejša čistilna naprava Domžale-Kamnik (200.000 PE - sekundarno čiščenje), ki pa je tudi preobremenjena. V podeželskih naseljih, zlasti v hribovitih predelih, pa je nasploh problem neurejene kanalizacije, saj se odpadne vode odvajajo $\mathrm{v}$ pogosto nepravilno urejene greznice ali pa naravnost $\mathrm{v}$ tla oziroma vodotoke, kar je še posebej neprimerno na kraških in vodovarstvenih območjih ter poljih z visoko gladino podtalnice (Regionalni..., 2002).

Regija po onesnaženosti podtalnice v slovenskem merilu ne izstopa izrazito, saj na večini območij mejne vrednosti polutantov niso presežene, z izjemo doline Kamniške Bistrice, kjer je podtalnica obremenjena zlasti s pesticidi in je bila tudi leta $2000 \mathrm{v}$ posameznih vzorcih ponovno presežena njihova mejna vrednost (Monitoring kakovosti podtalnic..., 2001). Kljub temu so obstoječi pritiski vendarle preveliki, če upoštevamo, da je podtalnica glavni vir pitne vode za večino prebivalstva v regiji (Ljubljana, Domžale), le južno ležeče občine se napajajo pretežno iz kraških izvirov (Regionalni..., 2002). V bodoče bo potrebno večjo pozornost namenjati tudi določitvi vodovarstvenih pasov in doslednemu nadzoru $\mathrm{v}$ 
njih. Omenjenim problemom se tudi z vidika varovanja voda pridružuje še problematika neurejenega odlaganja odpadkov; od množice divjih odlagališč (v gramoznicah, kraških jamah ipd.) do tveganih lokacij obstoječih komunalnih odlagališč, kot npr. v Logatcu zaradi krasa ter na Vrhniki, v Litiji in Ljubljani zaradi lokacije odlagališča na poplavnem območju (Poročilo..., 2002).

Iz navedenega je razvidno, da prihaja $v$ delih regije, ki sovpadajo $s$ t.i. vročimi točkami, do križanja interesov kmetijstva, poselitve, vodne oskrbe, prometa in drugih gospodarskih dejavnosti. Na drugi strani pa na podeželju primanjkuje gospodarskih jeder, raven storitev, predvsem komunalne, pa tudi prometne in komunikacijske infrastrukture pa je nižja, saj jo je zaradi razpršene poselitve težje zagotavljati.

V sklepnem delu proučitve razvojnih problemov želimo odgovoriti še na vprašanje, kakšno težo imajo navedeni gospodarski, socialni, prostorski in okoljski problemi Ljubljanske urbane regije $\mathrm{v}$ državnem merilu. Po raznih merah razvoja se namreč LUR uvršča na prvo mesto med slovenskimi statističnimi regijami. Tako je regija vodilna glede na najnižji indeks razvojne ogroženosti, ki temelji na uporabi dveh kazalcev: deleža prebivalstva $\mathrm{v}$ območjih s posebnimi razvojnimi problemi v okviru regije in sintezne ocene razvojnih možnosti regije. Indeks torej predstavlja kombinacijo stanja trenutne razvojne problematike in ocene razvojnih možnosti regije (Strategija..., 2001), njegov končni izračun pa je temeljil na ponderiranju skoraj 40 različnih socialnih in ekonomskih kazalcev. Druga sintezna mera razvoja je indeks človekovega razvoja, ki se s postopki standardizacije pridobi iz treh osnovnih kazalcev: zdravja (pričakovana dolžina življenja), izobrazbe (iz stopnje pismenosti in bruto vpisnega količnika osnovnega, srednjega in visokega izobraževanja) in življenjskega standarda (BDP po kupni moči) (Poročilo o človekovem..., 2001). Tudi po tem mednarodno priznanem indeksu, ki vključuje le socialne in ekonomske kazalce, je LUR na prvem mestu v državi. Bolj diferencirano sliko pa pokaže izračun t.i. kazalca sonaravnega regionalnega razvoja, ki je pridobljen $\mathrm{z}$ agregiranjem izbranih kazalcev za ekonomsko, socialno in okoljsko področje. Tudi po končni vrednosti tega kazalca se je regija sicer uvrstila na prvo mesto, vendar so se pokazale velike razlike med rangi regije za posamezna vključena področja razvoja. Skupno prvo mesto regije je tako pretežno zasluga izjemno visoke prednosti na ekonomskem področju, medtem ko je na socialnem področju zasedla drugo mesto, na okoljskem pa si je delila šele deveto do deseto mesto med dvanajstimi statističnimi regijami (Vintar, 2003). Slednje nas navaja na domnevo, da se trenutni razvoj regije v veliki meri odvija na račun okolja, kar pa lahko ob vseh ostalih v prispevku predstavljenih problemih dolgoročno zmanjša njene razvojne možnosti.

\section{SKLEP}

Ljubljanska urbana regija je gospodarsko najrazvitejša slovenska regija. Ključno vlogo v njenem urbanem sistemu igra Ljubljana kot glavno mesto države in močno središče $\mathrm{z}$ večino prebivalstva, razpoložljivih delovnih mest in razvejanimi gospodarskimi dejavnostmi. Navzlic splošno dobri oceni razvojnih možnosti pa se poraja tudi vrsta dilem glede nadalj- 
njega razvoja regije. Poglobljena analiza obstoječih procesov in stanja v celotni regiji je tako opozorila predvsem na naslednji specifični splet razvojnih problemov:

1. visoki življenjski stroški (vključno s cenami nepremičnin), ki jih nekateri prebivalci ne zmorejo več in zato zapuščajo regijo;

2. odlivanje kapitala iz regije in finančni problemi največje občine;

3. izgube $\mathrm{v}$ tradicionalnih industrijskih panogah;

4. visoka stopnja brezposelnosti med delavci z nižjimi stopnjami izobrazbe;

5. intenzivni prometni tokovi ob hkratnem upadu pomena javnega transporta;

6. potratna prostorska struktura poselitve;

7. širjenje pozidanih površin predvsem na račun kmetijskih zemljišč in območij pomembnih za vodno oskrbo;

8. slabšanje kakovosti zraka in drugih sestavin okolja zaradi naraščanja prometa;

9. onesnaževanje vodnih virov;

10. križanje interesov kmetijstva, poselitve, vodne oskrbe, prometa in drugih gospodarskih dejavnosti.

Opredeljeni razvojni problemi regije so večinoma povezani z:

1. decentralizacijo prebivalstva, ki ji ne sledi ustrezna decentralizacija delovnih mest;

2. zgoščevanjem človeškega kapitala in storitvenih dejavnosti $\mathrm{v}$ regiji zaradi njenih $\mathrm{v}$ primerjavi z drugimi regijami v Sloveniji najboljših razvojnih možnosti;

3. prevelikim opiranjem le na funkcijo Ljubljane kot glavnega mesta in premajhnim uveljavljanjem primerjalnih prednosti regije $\mathrm{v}$ širšem evropskem prostoru.

Glede na opisane procese in težnje $v$ razvoju regije ter prepoznane razvojne probleme lahko sklepamo, da ima Ljubljanska urbana regija vse značilnosti zgostitvenega tipa problemskih regij. Kakovost življenja se tako zaradi povečanih okoljskih pritiskov in visokih življenjskih stroškov že zmanjšuje.

Kljub temu pa ni mogoče pristati na tezo o regionalni homogenosti. Znotraj regije se nahajajo posamezne (podeželske) subregije, ki se srečujejo z drugačnimi razvojnimi problemi kot prebivalstvena aglomeracija v širši okolici Ljubljane. Toda celotna regija ima na strateški ravni vsaj eno povezavo - mesto Ljubljana, ki s svojo gospodarsko močjo, prometnimi potmi, dnevno migracijo prebivalcev na delo in drugimi strateškimi povezavami povezuje regijo v homogeno celoto.

Ljubljanska urbana regija se nahaja na pomembni razvojni prelomnici. Vsi regionalni akterji bodo morali v bližnji prihodnosti preseči nasprotja in premagati medsebojno nezaupanje, saj se bodo lahko le na ta način izvajali načrtovani razvojni programi, s katerimi se bo lahko ustrezno odgovorilo na številne gospodarske, socialne, prostorske in okoljske probleme v regiji. V nasprotnem primeru lahko najrazvitejša, najuspešnejša, najboljša regija v Sloveniji postane zaviralec razvoja celotne države. Takrat bo prepozno: Ljubljanska urbana regija bo problemska regija. 


\section{Viri in literatura}

Allen, J., Charlesworth, J., Cochrane, A., Court, G., Henry, N., Massey, D., Sarre, P., 1998. Rethinking the region. London and New York. Routledge, 159 str.

Armstrong, H., Taylor, J., 2000. Regional Economics and Policy. Oxford, Blackwell Publishers, $437 \mathrm{str}$.

Bradeško, J., 2003. Trg nepremičnin in Centralna banka. V: Poslovanje z nepremičninami. 14. tradicionalno strokovno srečanje. Zbornik referatov. Portorož, str. 84-91.

Cirman, A., Zupančič, D, 2003. Lokacijska renta kot element najemnine. V: Poslovanje z nepremičninami. 14. tradicionalno strokovno srečanje. Zbornik referatov. Portorož, str. 176-180.

Černe, A., 2002. Javni potniški promet kot izraz gravitacijske moči Ljubljane. V: Geografija Ljubljane. Ljubljana, Oddelek za geografijo Filozofske fakultete Univerze v Ljubljani, str. 191-213.

Discuss the implication of membership of the European Union for problems and policies of regional development in Britain. 1991. Univerzitetni eseji. Geografija.

URL: http://studentcentral.co.uk/coursework/essays/275.html (citirano: 18.7.2002)

Dolenc, D., 2000. Prostorska mobilnost prebivalstva. V: Ljubljana - geografija mesta. Ljubljana, Ljubljansko geografsko društvo, Založba ZRC, str. 81-92.

Gabrovec, M., Pavlin, B., Sluga, G., 2000. Dostopnost do javnega potniškega prometa v Ljubljanski urbani regiji. V: Ljubljana - geografija mesta. Ljubljana, Ljubljansko geografsko društvo, Založba ZRC, str. 251-256.

Gulič, A., Praper, S., 2000. Koncept regionalnega prostorskega razvoja Slovenije. Geographica Slovenica 33, II., str. 133-174.

Kebrič, I., Mrzlikar, S., 1983. Problematične regije v planiranju. Ljubljana. Inštitut za ekonomska raziskovanja, $41 \mathrm{~s}$.

Kušar, S., 2003a. Problemska regija kot element za zasnovo regionalnega razvojnega programa: magistrsko delo. Ljubljana, Filozofska fakulteta, Oddelek za geografijo, $147 \mathrm{s.}$

Kušar, S., 2003b. Zasavje: a problem region. V: Regionalno razvojna problematika Bosne i Hercegovine i susjednih zemalja u procesu približavanja Evropskoj uniji. Mednarodni naučni seminar. Tuzla, Prirodno-matematićki fakultet, Odsjek za geografiju, s. 201-212.

Monitoring kakovosti podtalnic za leto 2000 - zvezek 1. 2001. Maribor, Zavod za zdravstveno varstvo Maribor, Inštitut za varstvo okolja, 106 str.

Monitoring kakovosti podtalnic za leto 2000 - Program G: Ljubljansko polje in Ljubljansko barje. 2001. Ljubljana, Inštitut za varovanje zdravja Republike Slovenije, 67 str.

Monitoring kakovosti površinskih vodotokov v Sloveniji v letu 1999. 2001. Ministrstvo za okolje in prostor, Agencija Republike Slovenije za okolje, 33 str.

Onesnaženost zraka v Sloveniji v letu 2000. 2002. Ljubljana, Ministrstvo za okolje in prostor, Agencija Republike Slovenije za okolje, 88 str.

Pečar, J., 2002. Regionalni vidiki razvoja Slovenije (in poslovanje gospodarskih družb v letu 2001). Ljubljana, Del. Zvez. Urada za makroekonomske analize in razvoj, 11, 7, 159 str.

Poročilo o človekovem razvoju - Slovenija 2000-2001. 2001. Hanžek, M., Gregorčič, M., (ur.). Ljubljana, Urad RS za makroekonomske analize in razvoj, 135 str. 
Poročilo o stanju okolja 2001/02 (končni predlog poročila). 2002. Ljubljana, Ministrstvo za okolje, prostor in energijo. URL: http://www.gov.si/mop (citirano: 28.12.2002).

Pšunder, I., Ferlan, N., 2003. Analiza stanovanjskih transakcij. V: Poslovanje z nepremičninami. 14. tradicionalno strokovno srečanje. Zbornik referatov. Portorož, str. 194-199.

Ravbar, M., 2002. Suburbanizacijske težnje v razvoju prebivalstva in delovnih mest v Ljubljanski mestni regiji. V: Geografija Ljubljane. Ljubljana, Oddelek za geografijo Filozofske fakultete Univerze v Ljubljani, str. 215-233.

Rebernik, D., 2003. Ljubljanska urbana regija - razvojni trendi, problemi in možnosti. V: Priložnosti in možnosti regionalnih struktur na poti k združeni Evropi. Ljubljana, Filozofska fakulteta, Oddelek za geografijo. (Dela, 19, str. 165 - 175)

Regional Inequalities. Geo Factsheet. April 2001, št. 113.

Regionalni razvojni program Ljubljanske urbane regije za obdobje 2002-2006. Strateški in izvedbeni del programa. 2002. Ljubljana, Regionalna razvojna agencija Ljubljanske urbane regije, $155 \mathrm{str}$.

Repovž, G., 2004. Žrtev nerealiziranih metropolistov. Ljubljana, ujetnica predsodkov. Delo. Sobotna priloga, 46, 31. januar 2004, str. 8-10.

SRRS: Strategija regionalnega razvoja Slovenije. 2001. Ljubljana, Ministrstvo za gospodarstvo, Agencija RS za regionalni razvoj, 37 str.

Statistični letopis Republike Slovenije. 2003. Ljubljana, Statistični urad Republike Slovenije, 668 str.

Šabić, D., Lojović, H. R., Tretjak, A., Skumavec, D., 2000. GIS-supported National Inventories, Based on Regularly Updated Land Cover Thematic Layer, Derived From Remote Sensed Data. V: Statistična omrežna sodelovanja za večjo evropsko usklajenost in kakovostno delovanje. Ljubljana, Statistični urad Republike Slovenije, str. 294-302.

Trajnostni razvoj Mestne občine Ljubljana. 2002. Strategija. Ljubljana, Mestna občina Ljubljana, Oddelek za urbanizem, 85. str.

Vintar, K., 2003. Okoljevarstveni vidiki sonaravnega regionalnega razvoja Slovenije: magistrsko delo. Ljubljana, Filozofska fakulteta, Oddelek za geografijo, 179 str.

\section{LJUBLJANA URBAN REGION - A PROBLEM REGION?}

\section{Summary}

The Ljubljana urban region is usually not described as a problem region, which is because the development problems are much more pressing in other parts of Slovenia. It is economically the most successful region which extends over one-eighth of the state territory, provides almost one-third of jobs in Slovenia and contributes an even higher share of gross domestic product. This paper, however, points to a specific set of problems faced by the Ljubljana urban region as a typical agglomerative region.

Despite their economic development or because of it, agglomerative regions may be a special type of problem regions. Rapid economic development, accelerated population growth, 
agglomerating of economic activities, jobs, research and development activities, cultural and administrative institutions may have certain "agglomerative" side effects which gradually lead to economic, social, demographic, urban, environmental and spatial development problems of the region. In an in-depth analysis of the situation and processes in all these spheres of the Ljubljana urban region, the following development problems were identified:

1. high costs of living (including the real estate prices), which some inhabitants can no longer afford to pay and are consequently leaving the region;

2. outflow of capital from the region and financial problems of the Ljubljana City Municipality;

3. losses in traditional industrial activities;

4. high rates of unemployment among workers with low levels of education;

5. intensive traffic flows and a parallel reduced importance of public transport;

6. wasteful spatial structure of settlement;

7. expansion of built-up areas at the cost of agricultural land and water supply areas;

8. deterioration of air quality and other environmental impacts resulting from increased traffic;

9. pollution of water resources;

10. conflict of interests related to agriculture, settlement, water supply, traffic and other economic activities.

Parallel to identifying the development problems of the region, it turned out that developmental non-homogeneity of the region resulted in agglomeration of population and activities in what is known as "hot spots", where these problems are consequently the most acute. In the Ljubljana urban region, the area of the Ljubljana City Municipality stands out the most in this sense. Most of the identified development problems in this region are related to:

1. decentralisation of population which fails to be matched by decentralisation of jobs;

2. agglomeration of human capital and services in the region because of the best development opportunities compared to other regions;

3. too great an emphasis on the function of Ljubljana as a capital and an insufficient emphasis on using comparative advantages of the region in a wider European area.

These development processes, tendencies and problems of the region confirmed our hypothesis that Ljubljana urban region has all the main characteristics of the agglomerative type of problem regions. Although in terms of some aggregated indicators of development (index of development threat, human development index, sustainable regional development index), the region is still ranked at the very top of Slovenian regions, there are quite justified doubts about its long-term development opportunities in the event that the existing development pattern continues. Accumulating and reproducing development problems and in particular reducing the quality of life and the environment may in fact hold back the economic development in the future. This, in turn, would not have consequences only on the local and regional levels but also on the level of the state. 